\title{
Aksara Lontarak Potential As A Symbol Of Musical Notated Of Makassar Traditional Drum On Learning Music Tradition In Pgsd Fip UNM
}

\author{
Sayidiman ${ }^{1}$, Andi Ihsan ${ }^{2}$, Hikmawati Usman ${ }^{3}$ \\ \{Sayidiman@unm.ac.id1 , andi.ihsan@unm.ac.id2, hikmawatiusman@unm.ac.id3 \} \\ ${ }^{1,2,3}$ Universitas Negeri Makassar, +62812106996431, +6281241113366, Indonesia
}

\begin{abstract}
The problem in this research is how the potential characters as symbols penotasian lontarak drum musical instrument Makassar from the aspect of its use as a notation? And how potential lontarak characters as symbols of musical instrument drum Makassar penotasian of aspects of the learning needs of traditional music in PGSD Faculty of Education University of Makassar ?. Samples numbered 87orang spread across three regions namely Makassar, Bone and Pare Pare. This type of research dskriptif, Data was collected through questionnaires and literature review, further analysis of the data by descriptive quantitative and qualitative descriptive. The results showed that students need a system PGSD penotasian accordance with the characteristics of Makassar drum instrument, and script lontarak been developed as a drum notation in the ISMS system that could potentially be developed as a script lontarak drum penotasian system Makassar.
\end{abstract}

Keywords: music notation, notation development, script lontarak, traditional notation, Makassar.

\section{Introduction}

Music education, including listening to music, making music and cognition of music which refers to harmony, tone, shape and structure of the music. For some educators, music education can be used not only to develop musical skills, but also to develop individual social skills, problem solving skills, cognitive skills, critical thinking dispositions and skills as well as academic achievement. 
Learning the art of music in PGSD FIP UNM is one of the required courses with a weight of 2 credits, with the aim of courses equip musical knowledge and skills to students as one of the competencies required of graduates profile PGSD students who become teachers in primary classes. As future teachers, the students demanded to master at least five principal areas of study plus the subject material Arts and crafts (SBDP) which charge material is the material the art of music, art and dance.

Music learning materials in PGSD load on the theory and practice of applying the instrument in learning western music theory with a system of beams and notation notational numbers. Excellent notation system used for music education regarding western musical instruments for example piano, pianika, and so on. being excellent numeral notation system used for vocal music education concerns. The problems that arise then are in PGSD music education not only about western music, but also learned about the music traditions, one of which is a drum instrument Makassar as a rhythmic instrument.

Notation system in music education is a formal representation system used for reading and writing musical ideas. Sound as a form of audio and digested through the sense of hearing can be realized in a visual form through the notation system. Against a form of sound in visual form, a person's ability to read and write notation is the absolute must-have. One of the difficulties students learn traditional musical instruments are the absence of an appropriate notation system, especially in learning a musical instrument drum tradition Makassar.

Lontarak script as a symbol for the people of Makassar language used as the language spoken and written language. Sugira[1]mentions three types of letters lontarak in Makassar ethnic communities namely lontarak Toa (lontarak jangang-jangang), Lontarak said-told, and New Lontarak. Lontarak latter learned in formal schooling curriculum of Basic Level to High School as Local Studies lessons in South Sulawesi, even in college (for those who have the local curriculum) included in the study program PGSD FIP UNM.

Based on the initial study of the alphabet lontarak, there are some characters that fits penyebutannya with the sound produced by the instrument drum Makassar, some of these lelvi $\sim \sim \sim$ that Latin script each of these symbols sequentially read "Da-TaKa-Pa". each symbol symbolism of the letter can be marked vowel sound to alter pronunciatior $\boldsymbol{V}$ or example the word of $\quad$ if given the vowel in the form of a dot $\boldsymbol{V}$, the bottom can be read DU ( ) which can be used to write the sound of "dung" from Makassar drum that sounds like it if part of the membrane on the head drum beating by using babbala (sort of stick to beat the drum is made of buffalo horn).

Exposure based on the previous paragraphs, the formulation of the problem in this research are:

1. how potential lontarak characters as symbols penotasian Makassar drum musical instruments from the aspect of its use as a notation?.

2. how potential lontarak characters as symbols of musical instrument drum Makassar penotasian of aspects of the learning needs of traditional music in PGSD Faculty of Education University of Makassar?.

\section{The research method}

\section{Types of research}

Type of this research is descriptive research as basic research that targets potential Lontarak script to be used as a musical instrument drum penotasian system Makassar to learning a musical instrument in the tradition of FIP UNM PGSD Studies Program. in the implementation peneitian, will develop an initial hypothetical model tested is limited to the 
student who has programmed music art education courses, then the hypothetical model will be developed through a model of R \& D in the year to the second and third research.

\section{Setting and research subjects}

The study was planned to be held in the Campus IV Makassar State University Prodi PGSD FIP UNM located on the street Tamalate Raya Makassar, the research subjects were the students of the study PGSD Makassar campus force in 2017, amounting to 115 0rang. The study population was a student PGSD 2017 FIP UNM force numbering 115, sampling is done with reference to the formula Slovin The calculation is:

$$
\begin{aligned}
& \mathrm{n}=\mathrm{N} /\left(1+\left(\mathrm{N}_{\mathrm{x} \mathrm{e}} \mathrm{e}^{2}\right)\right) \\
& \text { Thus: } \mathrm{n}=115 /\left(1+\left(115 \times 0,05^{2}\right)\right) \\
& \mathrm{n}=115 /(1+(115 \times 0.0025)) \\
& \mathrm{n}=115 /(1+0.2875) \\
& \mathrm{n}=115 / 1.2875 \\
& \mathrm{n}=89.32
\end{aligned}
$$

so the number of samples is 89 people with the proportion of each campus PGSD consisting of three college campuses namely Makassar, Pare Pare, Bone and get a portion of the sample balanced then:

$$
\begin{aligned}
& \mathrm{n}=89 / 3 \\
& \mathrm{n}=29
\end{aligned}
$$

then the number of samples of each region of the campus is 29 people.

\section{Data collection technique}

Data were collected through questionnaires technique on the students' needs PGSD need a notation system in accordance with the characteristics of traditional musical instruments Drum Makassar. Further data on whether or not the script lontarak used as a system of symbolic notation Makassar drum instrument obtained through the study of literature.

\section{Data analysis technique}

Data were obtained through a questionnaire the students' needs were analyzed through quantitative descriptive techniques. questionnaire was distributed to a sample study in three regions of different campuses namely Makassar PGSD UPP, UPP and UPP PGSD PGSD Bone Pare Pare, each region was represented by a sample of 29 people. Furthermore, data from the questionnaire is made in the form of a score with a scoring rubric based on the questions as follows:

Table 1. rubric score of questions questionnaire.

\begin{tabular}{|llll}
\hline \multicolumn{2}{l}{ rubric score of questions questionnaire } \\
\hline \\
no questions & yes & no & Information \\
$\mathbf{1}$ & 1 & 0 & \\
$\mathbf{2}$ & 1 & 0 & \\
$\mathbf{3}$ & 1 & 0 & \\
$\mathbf{4}$ & 1 & 0 & \\
$\mathbf{5}$ & 1 & 0 & \\
\hline
\end{tabular}




\begin{tabular}{|c|c|c|}
\hline 6 & 1 & 0 \\
\hline 7 & 1 & 0 \\
\hline 8 & 1 & 0 \\
\hline 9 & 1 & 0 \\
\hline \multirow[t]{3}{*}{10} & 1 & 0 \\
\hline & 10 & 0 \\
\hline & $\max$ score & $\begin{array}{l}\text { score } \\
\text { min }\end{array}$ \\
\hline \multicolumn{3}{|c|}{ if yes means strengthen research } \\
\hline \multicolumn{3}{|c|}{$\begin{array}{l}\text { if the answer does not } \\
\text { assumption peneltian }\end{array}$} \\
\hline \multicolumn{3}{|c|}{ lontara alphabet requirement criteria } \\
\hline $0-7$ & No need & \\
\hline 8-10 & Need & \\
\hline
\end{tabular}

was the result data literature review analyzed by through qualitative descriptive technique.

\section{Research result}

Research through a questionnaire targeting techniques PGSD Science faculty student needs Makassar State University study on the potential development of symbolic notation system in accordance with the characteristics of traditional musical instruments drum Makassar. Based on the results of questionnaire data showed that in the regionUpp Makassar $72 \%$ or 21 of 29 respondents stated that require and is $27 \%$ or 8 out of 29 respondents who expressed no need of being in the region of Upp bone $72 \%$ or 21 of 29 respondents stated that require and is $27 \%$ or 8 of 29 respondents saying no next to the area requiring Upp Parepare $75 \%$ or 22 of 29 respondents stated that require and is $27 \%$ or 7 out of 29 respondents saying do not need.

Overall results of the questionnaire for a potential student needs developed script lontarak Makassar drum notation system as described in the following table:

Table 2.Student need the new notation accordance with traditonal music in three

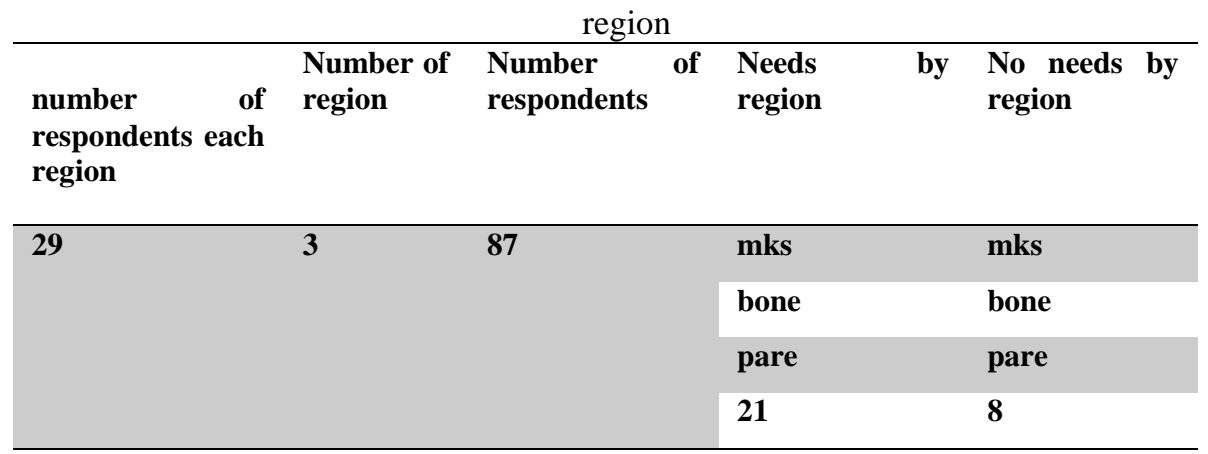




\begin{tabular}{lll}
\hline & 21 & 8 \\
& 22 & 7 \\
Total & 64 & 23 \\
percentage & 73.56 & 26.44 \\
\hline
\end{tabular}

The results based on the review of the literature data showed that lontarak script ever developed as a system of musical notation by Syamsul Qamar a teacher in secondary school tanaga Karawitan Indonesia (ISMS) Somba Opu in 1980 as noted by anthropologist Anderson[2]: Efforts sporadic to develop musical notation drum in Makassar has been done in previous years but later in 1980, when the musicians, a music teacher at South Sulawesi trying denote drum and Syamsul Qamar a teacher of music in the ISMS contributed one approach that is using lontarak letter ... among music teachers, this notation is hotly debated, they complained that the use of this symbolism systems become unnecessary barriers in the learning process.

Table 3.Table of Syamsul Qamar notation

\begin{tabular}{|c|c|c|c|c|c|}
\hline $\begin{array}{l}\text { No } \\
\text {. }\end{array}$ & name blow & $\begin{array}{l}\text { The } \\
\text { resulting } \\
\text { sound }\end{array}$ & $\begin{array}{l}\text { Symbolism } \\
\text { notation in } \\
\text { script } \\
\text { lontarak }\end{array}$ & $\begin{array}{l}\text { Riot } \\
\text { sound } \\
\text { in latin }\end{array}$ & A brief description \\
\hline 1 & Tumbuk & dung & 1 & $\mathrm{D}$ & $\begin{array}{l}\text { Hand hit near the end of a large } \\
\text { drum head }\end{array}$ \\
\hline 2 & Tunrung & tung & + & $\mathrm{T}$ & $\begin{array}{l}\text { Hand drum head hitting the center } \\
\text { of the membrane using babbalak } \\
\text { (beater) }\end{array}$ \\
\hline 3 & Palappek & not & & $\mathrm{T}$ & $\begin{array}{l}\text { Hand hit the middle of the head } \\
\text { drum and not be removed }\end{array}$ \\
\hline 4 & tempa & $K a k$ & & $\mathrm{~K}$ & $\begin{array}{l}\text { Drum membrane ass slapping the } \\
\text { edge }\end{array}$ \\
\hline 5 & Pamaccing & plaque & & $\mathrm{P}$ & $\begin{array}{l}\text { Left and right hands } \\
\text { simultaneously hitting the drum } \\
\text { membrane with palms }\end{array}$ \\
\hline 6 & Balakbak & $\begin{array}{l}\text { Dak, } \\
\text { smack, cis, } \\
\text { plek }\end{array}$ & & $\mathrm{D}$ & Hitting the drum body \\
\hline
\end{tabular}

\section{Discussion}

Based on research data on the potential student needs lontarak characters as symbols of traditional musical instruments Drum penotasian Makassar is in the category is quite high, in other words, students need it. Each region of the three regions the population indicates the level of the different needs although the level difference was not significant. The high demand 
mismatch indicates notation system used so far in learning a musical instrument drum Makassar, it is consistent with the statement[3] researching on traditional notation in Music History Turkey, Cemal revealed that western music theory is contrary to the tradition of music in the understanding of traditional music as a medium for character education and transference.

Research data also shows that there are some students who do not need a new system to learn drum penotasian Makassar. Based on follow-up interviews with respondents who do not require revealed that, learning a musical instrument tradition should be done with oral system through direct contact with the drum music artist plaku Makassar tradition, it is supported by the opinion[4]who explained that the cultural inheritance of the people, they internalize the culture through oral culture or commonly called folklore. Folklore is part of a collective culture, which is inherited from generation to generation, the collective range of anything, traditionally in different versions, either verbally or examples are accompanied by gestures or auxiliaries reminder.

Literature study gives clues about potential characters as symbols penotasian drum Lontarak Makassar. This perlambanagan system ever initiated by Syamsul Qamar as noted by anthropologist[2], The weakness of the symbolism of the notation system initiated by Syamsul Qamar not use the value of not making it difficult for learners to read with appropriate notation. As in music theory that value not specify the duration of how long a note is sounded. The long duration of short notes related to other notes pose a rhythm accentuation in detail, as expressed by[5]that the term notation is a formal system to signal between musicians and music teaching system to memorize and syllables, words or phrases spoken. 'The reading of the view and notate' is an important element in learning music. The purpose of notation is to transfer the example of music literature and folk music to the next generation and thereby protect the public musical culture.

Cultural inheritance through notated system allows the culture heritages itself once can be a publication and global literacy as by[5]further stated that natural musical communication system of society, sight reading and marking the natural notation symbols for musicians and allow them to track and control the music culture. However, someone who has no knowledge of notation has its own teaching techniques and learning to manipulate and transfer the music in the culture.

The concept of learning music using the notation system is capable of creating selflearning conditions so that the learning process can be more meaningful. With self-learning, learners and learning themselves memenej construct knowledge. The role of educators in learning conditions as it changed from the teacher as facilitator and mediator between learning resources by participants learn, dikemukakakn by[5]notation system must be introduced effectively in order to be able to see music as an art that is effective, and encourage people to make music as a lifetime activity. It is important to understand music education methods and used efficiently to provide music for everyone to learn throughout their lives.

Another thought that may arise from this research is a necessary caution in interpreting the idiom and cultural traditions into a standard system. Traditional art was born and developed in community supporters are certainly not merely as an attractive work but also contains elements of local wisdom sebagimana addressed by[5]that stated that most of the music curriculum includes traditional music genre that aims to preserve the local musical traditions. However, it seems that what is inherited is more on the music than the actual context of the music. For example, the notation used in part to facilitate and speed up the learning process and learning problems associated with traditional music orally is not emphasized. Implications regarding the authenticity of a tradition when designing teaching local musical traditions may 
not be considered. Establish an accurate context for the practical activities of the gamelan can not only provide a good methodology but also allow proper evaluation.

Translation of idioms sound of drum Makassar into the visualization of the symbolism of sound in the form of systems symbolism of musical notation tradition also demonstrates the potential occurrence of acculturation intimate inter writing system standard notation in the west with the notation traditions of the drum in Makassar, this certainly has the potential to develop the science of music specifically and methods a particularly effective teaching music in learning a musical instrument drum tradition Makassar.

\section{Conclusion}

Based on the results of research and discussion in this study it can be concluded:

1. Lontarak script could potentially be developed as a system of symbolic notation especially those in Makassar drum traditional music instruments.

2. Lontarak alphabet potential as a music recording system can be a standalone solution for student learning needs. Penotasian system will be the bridge cultural gaps survival needs Makassar drum traditional music with his successor generation.

\section{References}

[1] S. Wahid, human Makassar, Makassar: Library Reflection 2008.

[2] RA Sutton, Pakkuru Sumange, Translation. Makassar: Ininnawa, 2013.

[3] C. Karabaşoğlu, "Tradition of Notation in the History of Turkish Music," Procedia Soc. Behav. Sci., Vol. 174, pp. 3832-3837, 2015.

[4] E. Fitrianita, F. Widyasari, and WI Pratiwi, "Building ethos and Local Wisdom through folklore: A Case Study in Tembalang Semarang folklore," endogamy J. Ilm. Kaji. Antropol., 2018.

[5] A. SultaNova and N. Bariseri, "conjectural and Absolute Solmization Systems in Music," Procedia - Soc. Behav. Sci., Vol. 46, pp. 2394-2397, 2012.

[6] Shahanum Mohamad Shah, "Popular music in Malasia: Education from the outside," Int. J. Music Educ., 2006. 